\title{
Ecological and taxonomic characterisation of Trentepohlia umbrina (Kützing) Bornet growing on stone surfaces in Lazio (Italy)
}

\author{
Flavia Bartoli ${ }^{1}$ (D) $\cdot$ Neil Thomas William Ellwood $^{1} \cdot$ Laura Bruno $^{2} \cdot$ Simona Ceschin $^{1} \cdot$ Lorenza Rugnini $^{2} \cdot$ Giulia Caneva $^{1}$
}

Received: 4 February 2019 / Accepted: 8 April 2019 / Published online: 15 May 2019

(C) Università degli studi di Milano 2019

\begin{abstract}
Purpose The colonisation of building material by photosynthetic organisms is highly dependent on the environmental conditions and the nature of the substrate. The growths of red-orange phototrophic biofilms have been widely reported in the literature and have commonly been associated with the order Trentepohliales, whose ecological and taxonomical information needs to be improved. Considering the recurrent presence of such biofilms throughout the Lazio region, we would identify the occurring species and define their favourable environmental conditions, through morphological, genetic and ecological analyses.

Results Biofilms were collected across an altitude range of 0 to $860 \mathrm{~m}$ asl, occurring from the coast to $60-\mathrm{km}$ inland. A dominant presence of the filamentous terrestrial green alga Trentepohlia umbrina (Kützing) Bornet was confirmed in all sites sometimes mixed with cyanobacteria of the genus Gloeocapsa. The distribution of Trentepohliales is generally given as pan-tropical, but some species, such as T. umbrina, are also distributed in temperate climates. Here, it is reported for the first time a Mediterranean occurrence of the species. Low humidity and light conditions, such as those occurring on vertical surfaces with mainly northern aspects, are the preferred environmental conditions. Coastal areas were more favourable for its growth, probably due to the higher nocturnal condensation that occurs here. Concrete and mortars were particularly bioreceptive to T. umbrina, but marble and trachyte were also colonised under favourable conditions.

Conclusions The findings better define the ecological range of this species, suggesting a wider biogeographic distribution, and adding information on morphological features and genetic data.
\end{abstract}

Keywords Biodeterioration patterns $\cdot$ Building material $\cdot$ Biofilm $\cdot$ Reddish patinas $\cdot$ Green algae $\cdot$ Trentepohlia umbrina

\section{Introduction}

Green subaerial microalgae can colonise natural and artificial substrata to form biofilms (Ricci and Pietrini 1994; Bellinzoni et al. 2003; Tomaselli et al. 2000; Rindi and Guiry 2004). Advanced growths of these biofilms are visible to the naked eye, forming patinas of different colours, such as green, grey and reddish, and giving rise to characteristic biodeterioration patterns (BP) (Caneva et al. 2016). They can often be considered as aesthetical biodeteriogens, but the potential for structural deterioration, caused by physical and biochemical

Flavia Bartoli

flavia.bartoli@uniroma3.it

1 Department of Science, University of Roma Tre, Viale G. Marconi 446, 00146 Rome, Italy

2 Department of Biology, University of Rome, 'Tor Vergata', Via Cracovia 1, 00133 Rome, Italy process, may have started before biofilms are even visible (Eggert et al. 2006; Scheerer et al. 2009; Bartoli et al. 2014). The occurrence of green algae and cyanobacteria biofilms on outdoor stone monuments and other artificial substrata, such as roof tiles, concrete or building facades, can exacerbate natural weathering phenomena (Caneva et al. 1992; Albertano 1995; Gaylarde and Morton 1999; Tomaselli et al. 2000; Gaylarde et al. 2004). Apart from the aesthetical impact of phototrophic biofilms, in some cases, they can also be considered as bioprotective of stone materials, even if this role has not been comprehensively demonstrated (Cutler and Viles 2010; Ramirez et al. 2010; Pinna 2014).

The occurrence of red-orange biofilms is often associated with the green algal order Trentepohliales, whose colour is resulting from their large production of $\beta$-carotene and haematochrome pigments. The order includes one family (Trentepohliaceae) and five genera (Trentepohlia, Printzina, Phycopeltis, Chephaleuurus, Stomatochroon), and originally had a pantropical distribution. The genus Trentepohlia comprises an 
accepted 48 species that are either subaerial or the phycobionts of several lichen species (Guiry and Guiry 2018). It has a global distribution and occurs on a wide range of substrates, such as tree bark, leaves, rock and several types of artificial substrata (Rindi and Guiry 2002; Rindi et al. 2005; Unković et al. 2017). Species of this genus can produce extensive yellow to red growths that can cover building walls, inscriptions and monument details, making necessary expensive active interventions, such as repainting and cleaning. Their growths have already been well documented and detailed described for some tropical areas, such East Asia (Wee and Lee 1980; Lee and Wee 1982; Ho et al. 1983; Bartoli et al. 2014) and Mesoamerica (Caneva et al. 2005; Gaylarde and Gaylarde 2005; Gaylarde et al. 2006; Ramirez et al. 2010; Ortega-Morales et al. 2012). Moreover, their occurrence has also been identified especially in North Europe, e.g. in Scotland (Wakefield et al. 1996), Ireland (Rindi and Guiry 2002) and in some Mediterranean area, such as Portugal (Pereira de Oliveira 2008) and Spain (Ariño and Saiz-Jimenez 1996).

Trentepohlia umbrina (Kützing) Bornet also seems to have a global distribution and is frequently defined as corticolous, found growing on the bark of deciduous trees and conifers, but it has also been found growing on woodwork, rocks, carved stone, concrete walls and pillars (see references in Guiry and Guiry 2018). Most of the available ecological information on this species is rudimentary and often based on the lichen-associated, rather than the free-living form. Rindi and Guiry (2002) gave the first report of the ecology of this species looking at its distribution in Galway (Ireland), where they found small isolated redbrown patches on north facing of old limestone walls only, with no observable seasonal variations.

Regardless of their desiccation tolerance, all terrestrial green algae require liquid water, or an atmosphere saturated with humidity, to be metabolically active. It should be therefore plausible to have a widespread distribution in Northern Europe, where humidity levels and rainfalls are usually higher, and by the same chain of thought, we expect a restricted distribution in Southern Europe. However, in central Italy, numerous observations of red-orange biofilms, presumably referred to Trentepohlia, at several archaeological and urban sites, suggest there is a need to re-determine the distribution and the ecological range of this species.

As robust ecological information regarding this species is lacking, there is a need for a more widespread study of its distribution, ecology and identification. Also, according to Rindi and Guiry (2002) and John (2002), the taxonomic characterisation of T. umbrina has not been satisfactorily defined, because of confusion with other species of the same genus. Some of the doubt regarding this species is from a morphological perspective. Therefore, the aims of this paper were to characterise in detail the ecology and the morphological features of T. umbrina colonising highly diverse environments and substrate types in the Lazio region, and, where possible, to support the identification of this species by molecular methods.

\section{Materials and methods}

\section{Study area}

The study area is the Lazio region (Central Italy), which has a surface of $17,227 \mathrm{~km}^{2}$, made up of various landforms, comprising hills (54\%), mountains $(26 \%)$ and plains $(20 \%)$ (Anzalone et al. 2010). The heterogenic orography, lithology and climatic gradient extending from the Tyrrhenian Sea to the central Apennines of Lazio region result in a series of different environment and vegetation types, representing 15 phytoclimate units (Blasi 1993; Anzalone et al. 2010; http:// www.pcn.minambiente.it). To define sites, numerous outings were organised based on the ecological information gathered from the literature (John 2002; Guiry and Guiry 2018), previous sightings and observations of satellite imagery available in GIS-based websites.

\section{Ecological data sampling}

Sampling sites were identified by the presence of visual redorange biofilms on stone surfaces, and field observations refer to a data set of 100 red-orange biofilms. For each red-orange biofilm, several ecological parameters were considered, such as the height of biofilm from the ground, aspects, sheltering, evidence of potential percolation, rising damp and shadowing of the surfaces, following usual protocols (Danin and Caneva 1990; Caneva et al. 2015; Traversetti et al. 2018). In evaluating the cover and the distribution of T. umbrina, the robust and repeatable phytosociological method of Braun-Blanquet (1964) was applied in the field. The cover-abundance of the biofilm was estimated according to the scale of BraunBlanquet $[+$ (very few individuals $)=0.5 ; 1$ (numerous individuals $)=1-5 \% ; 2=5-25 \% ; 3=25-50 \% ; 4=50-75 \% ; 5=$ $75-100 \%$ ]. These values were then converted in the van der Maarel abundance scale for statistical analyses (van der Maarel 1979).

For each site, covering the period from 2013 to 2017, to have an homogeneous dataset for all sites and considering also the conditions of a climatic change, meteorological data were collected from the Lazio region official website (http://www. idrografico.roma.it). In order to discern the bioclimatic preferences of $T$. umbrina (regarding pluviometry and temperatures), a bioclimatic map of the region was used (Blasi 1993; Anzalone et al. 2010; http://www.pcn. minambiente.it), and then thermo-pluviometric diagrams were constructed of the two localities at the extremities of the site climatic gradient, according to methods proposed by Bagnouls and Gaussen (1963).

In order to obtain general ecological information on lighting conditions, autumnal sun paths were superimposed over satellite images of each site (www.suncalc.org; www. sunearthtools.com). Using the autumnal sun path meant that 
we gave conservative light load values, this was done to even out seasonality because some aspects receive more light in the afternoon/evening and some aspects in the morning.

Ground observations were made during sampling to understand the sources of shading that may not be noticed on older satellite images. Values of light exposure (in min day ${ }^{-1}$ ) were divided into two diverse types, full and speckled exposure. The latter type was identified as many sites were surrounded and therefore shaded, by tree canopies, and the biofilms can be subjected to flecks of full solar irradiance.

\section{Morphological and molecular analysis}

For the morphological identification, sampling of biofilms involved either scraping of biomass from the substrate using clean razor blades or using adhesive fungi tape, a nondestructive method, for sites of cultural value (Bruno et al. 2014; Bruno and Valle 2017).

Microscopic observations (Zeiss Axio Scope) of fresh unfixed samples were observed on return to the laboratory or the day after (samples stored in the dark at $4{ }^{\circ} \mathrm{C}$ ) for cell measurement and identification following UNI 10923. Fresh un-fixed samples were always observed and photographed within $48 \mathrm{~h}$ for identification using a light microscope (Zeiss AxioScope). Initial identifications were made using the identifying morphological traits proposed by John (2002) and following the analytic keys of Guiry and Guiry (2018). To confirm the morphological characterisation, cell measurements were made using calibrated digital images. Measurements of length $(L)$, width $(W)$ and $L: W$ of 50 intercalary cells (the smaller apical cells were excluded) for 12 representative populations that covered the full range of substrate types were carried out.

Samples from the site Grassi Hospital were used for molecular identification of the species. Around $100 \mathrm{mg}$ of freshweight samples were repeatedly frozen and thawed (ca. 20 cycles) and DNA was extracted using the GeneMATRIX Plant and fungi DNA purification kit (EURx). The chloroplast gene $r b c \mathrm{~L}$ was amplified using the following primers: TrerbcL_mos_for (5'-GAAGCWATTCCRGGAGAAG-3') and TrerbcL_mos_rev (3'-CATCCATTCTTGAG WAAAGAATAC-5') (Eurofins Genomics, Ebersberg, Germany). Amplifications involved an initial denaturation at $94{ }^{\circ} \mathrm{C}$ for $3 \mathrm{~min}$; then 30 cycles of denaturing at $94{ }^{\circ} \mathrm{C}$ for $30 \mathrm{~s}$, annealing at $51^{\circ} \mathrm{C}$ for $30 \mathrm{~s}$, extension at $72{ }^{\circ} \mathrm{C}$ for $1 \mathrm{~min}$ and a final extension at $72{ }^{\circ} \mathrm{C}$ for $7 \mathrm{~min}$. Amplified fragments were sequenced on both strands at the BMR-Genomics Sequencing Service (Padua, Italy). The $r b c L$ gene sequence obtained was analysed using the BLAST function of GenBank (www.ncbi. nlm.nih.gov/blast), and phylogenetic analysis was carried out with the most similar sequences. The selected sequences were aligned with the Clustal Omega program (www.ebi.ac.uk/ Tools/msa/clustalo/). Maximum likelihood and neighbourjoining trees were generated using the PAUP*4.0 software package. Bootstrap values were obtained from 500 replicates with one random sequence addition to jumble the data using the PAUP. A neighbour-joining tree was constructed using MODELTEST v. 3.7. The rbcL sequences of Ulva australis Areschoug (EF372236) and Ulva linza L. (AB097620) were used as outgroup, and the tree was edited using TREEVIEW version 0.5.0. (R.D.M. Page).

\section{Statistical analyses}

Tests for normality and variance were carried out on morphological and environmental data using Q-Q-plots and Levene's test before ANOVA. Tukey's pair-wise Q post hoc tests were carried out in case of significant differences realised by the ANOVA. For non-normal data, in this case cellular $L$ and $W$, Kruskal-Wallace tests were used, followed up with Dunn's post hoc analysis with Bonferroni correction of $p$ values to identify sites significantly different from each other. The cover values were used to evaluate the influence of several ecological parameters on the growths of T. umbrina, such as (i) aspects, (ii) daily sunlight loads and (iii) substrate type. All statistical analyses were carried out using PAST3 and the Real Statistics Resource Pack software for excel (Release 5.4).

\section{Results}

\section{Ecological characterisation}

The sampling campaign highlighted nine different sites with distinctly diverse characteristics and a total of six substrate types: basalt, brick, concrete, white marble and two magmatic effusive rocks as peperino and trachyte. The sites, where the red-orange biofilms resulted more widespread, were located in three different provinces of Lazio (Rome, Viterbo and Frosinone), (Table 1).

The area covers a wide range of altitude, that is from sea level to $860 \mathrm{~m}$ asl (Fig. 1), and across diverse phytoclimates, ranging through a Mediterranean bioclimate (Fig. 2a), close to the coast, to a temperate bioclimate (Fig. 2b) in sub-mountain areas. Site altitude was positively and negatively correlated with 5-year mean values of precipitation $(p<0.01)$ and temperature $(p<0.05)$, respectively (Fig. $2 \mathrm{c}, \mathrm{d})$, whilst $\mathrm{RH}$ remained relatively unchanged (ca. 60-73\%; $p>0.05$ ). Annual precipitation (5-year mean) ranged from $550 \mathrm{~mm}$ at Santa Severa to $1550 \mathrm{~mm}$ at Trevi nel Lazio, whilst temperature (5-year mean) ranged from 12 (Trevi nel Lazio) to $19^{\circ} \mathrm{C}$ (Palatine Hill).

The field observations highlighted that, in favourable environmental conditions, this BP is very widespread and showing also an abundant cover (Fig. 3a). Moreover, it was evident how this BP is one of the first colonisers of the stone substrate 
Table 1 Site characteristics with detailed geographical and physical information and sites specific meteorological data

\begin{tabular}{|c|c|c|c|c|c|c|c|c|c|c|}
\hline \multirow[t]{3}{*}{ Prov. } & \multirow[t]{3}{*}{ Station } & \multirow{3}{*}{$\begin{array}{l}\text { Acronyms } \\
\text { map }\end{array}$} & \multirow[t]{3}{*}{ Coordinates } & \multirow[t]{3}{*}{ Substrate } & \multirow{3}{*}{$\begin{array}{l}\text { Altitude } \\
\text { (m asl) }\end{array}$} & \multirow[t]{3}{*}{ Inclination } & \multicolumn{4}{|c|}{ Methereological data (2013-2017) } \\
\hline & & & & & & & \multicolumn{3}{|c|}{$\begin{array}{l}\text { Mean annual temperature } \\
\left({ }^{\circ} \mathrm{C}\right)\end{array}$} & \multirow[t]{2}{*}{$\begin{array}{l}\text { Annual rainfall } \\
(\mathrm{mm})\end{array}$} \\
\hline & & & & & & & Min & Mean & Max & \\
\hline $\mathrm{RM}$ & Palatine Hill, Rome & PL & $\begin{array}{l}41^{\circ} 53^{\prime} 26^{\prime \prime} \mathrm{N} \\
12^{\circ} 29^{\prime} 16^{\prime \prime} \mathrm{E}\end{array}$ & Basalt/brick & 30 & $90^{\circ}$ & 13.46 & 18.84 & 24.22 & 800 \\
\hline $\mathrm{RM}$ & Grassi Hospital, Ostia & $\mathrm{GH}$ & $\begin{array}{l}41^{\circ} 43^{\prime} 49^{\prime \prime} \mathrm{N} \\
12^{\circ} 18^{\prime} 13^{\prime \prime} \mathrm{E}\end{array}$ & Concrete & 10 & $90^{\circ}$ & 11.57 & 16.48 & 21.06 & 785.86 \\
\hline $\mathrm{RM}$ & Ostia Antica archaeological park & $\mathrm{OA}$ & $\begin{array}{l}41^{\circ} 45^{\prime} 11^{\prime \prime} \mathrm{N} \\
12^{\circ} 17^{\prime} 17^{\prime \prime} \mathrm{E}\end{array}$ & Marble & 10 & $90^{\circ}$ & 11.71 & 16.31 & 21.14 & 785.86 \\
\hline $\mathrm{RM}$ & Non-Catholic Cemetery, Rome & $\mathrm{CA}$ & $\begin{array}{l}41^{\circ} 52^{\prime} 31^{\prime \prime} \mathrm{N} \\
12^{\circ} 28^{\prime} 43^{\prime \prime} \mathrm{E}\end{array}$ & Marble & $10-20$ & $90^{\circ}$ & 11.82 & 16.39 & 21.18 & 683.04 \\
\hline $\mathrm{RM}$ & $\begin{array}{l}\text { Santuario Madonna del Tufo, } \\
\text { Rocca di Papa }\end{array}$ & $\mathrm{RP}$ & $\begin{array}{l}41^{\circ} 75^{\prime} 63^{\prime \prime} \mathrm{N} \\
12^{\circ} 70^{\prime} 68^{\prime \prime} \mathrm{E}\end{array}$ & Brick & 693 & $90^{\circ}$ & 9.88 & 13.05 & 16.21 & 1165.72 \\
\hline $\mathrm{RM}$ & Santa Severa/S. Marinella & SS & $\begin{array}{l}42^{\circ} 2^{\prime} 17^{\prime \prime} \mathrm{N} \\
11^{\circ} 50^{\prime} 11^{\prime \prime} \mathrm{E}\end{array}$ & Concrete & $0-10$ & $90^{\circ}$ & 12.31 & 16.56 & 20.81 & 553.76 \\
\hline VT & Villa Lante, Bagnaia & LB & $\begin{array}{l}42^{\circ} 25^{\prime} 35^{\prime \prime} \mathrm{N} \\
12^{\circ} 09^{\prime} 20^{\prime \prime} \mathrm{E}\end{array}$ & Peperino & $420-470$ & $90^{\circ}$ & 11.25 & 16.42 & 21.6 & 810.14 \\
\hline VT & Bomarzo Garden & $\mathrm{BZ}$ & $\begin{array}{l}42^{\circ} 29^{\prime} 29^{\prime \prime} \mathrm{N} \\
12^{\circ} 14^{\prime} 43^{\prime \prime} \mathrm{E}\end{array}$ & Trachyte & $200-210$ & $90^{\circ}$ & 11.71 & 15.12 & 18.44 & 867.52 \\
\hline FR & Trevi nel Lazio & $\mathrm{TL}$ & $\begin{array}{l}41^{\circ} 51^{\prime} 1^{\prime \prime} \mathrm{N} \\
13^{\circ} 12^{\prime} 4^{\prime \prime} \mathrm{E}\end{array}$ & Concrete & 860 & $90^{\circ}$ & 6.22 & 11.74 & 17.27 & 1548.92 \\
\hline
\end{tabular}

(Fig. 3b), changes in cover in relation to the aspect and that it is usually associated to black patinas (Fig. 3c).

The changes in the cover of these biofilms in relation to the aspects of surfaces are shown in Table 2. A preference for northern and western aspects is clearly evident (Fig. 4a), and the cover of such BP on the north and north-west aspects accounted for nearly $49 \%(27.4 \% \mathrm{~N}$ and $21.6 \% \mathrm{NW}$ ) of the total mean cover for all aspects. Substrates with other aspects were also colonised, although to a lesser extent, with cover values of $10 \%$ or less of the total, and minimum values for south-facing aspects $(1.5 \%)$.

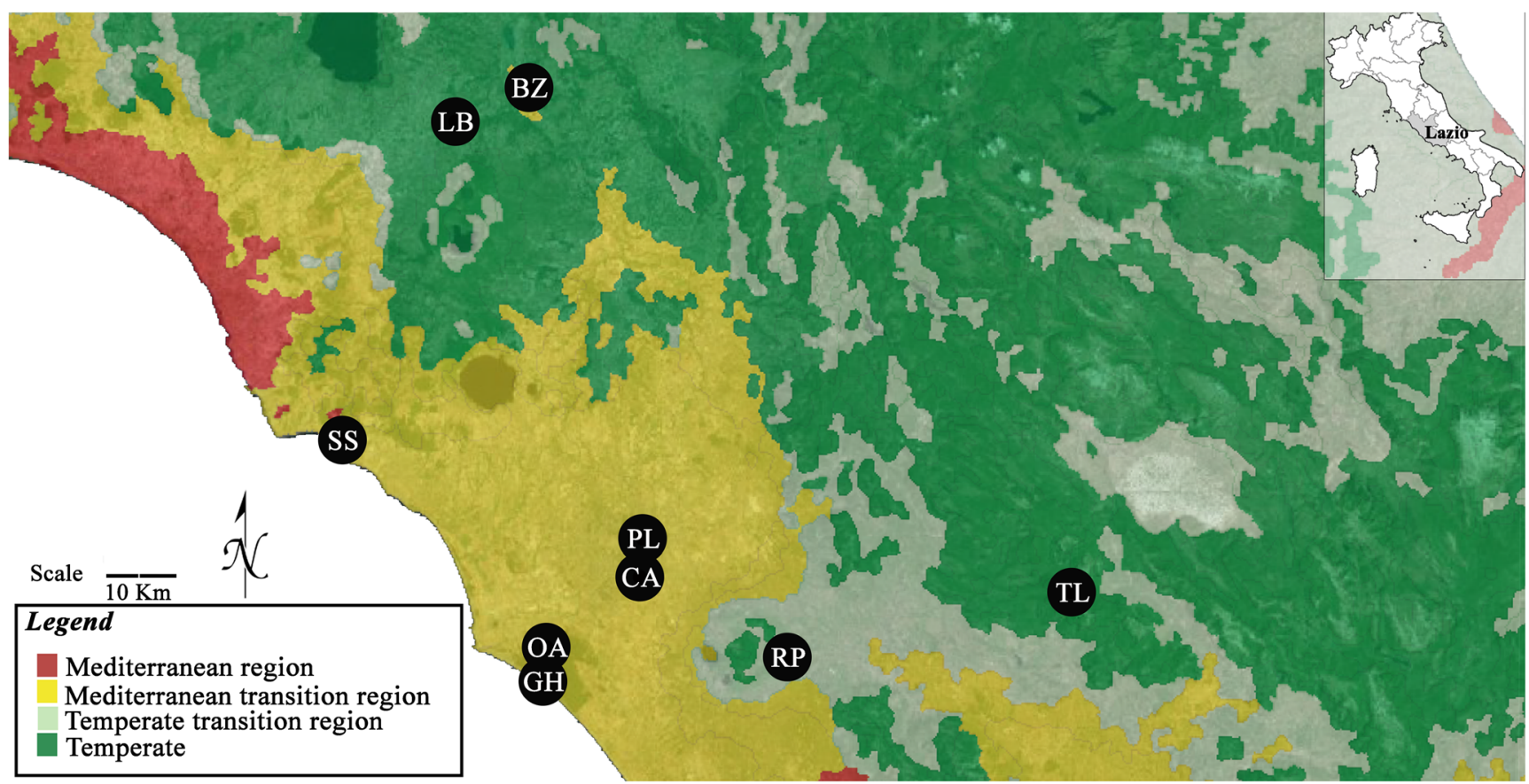

Fig. 1 Bioclimatic sites map: distribution of the analysed sites in the different bioclimatic region of the Lazio. The acronyms of the site are specified in Table 1 


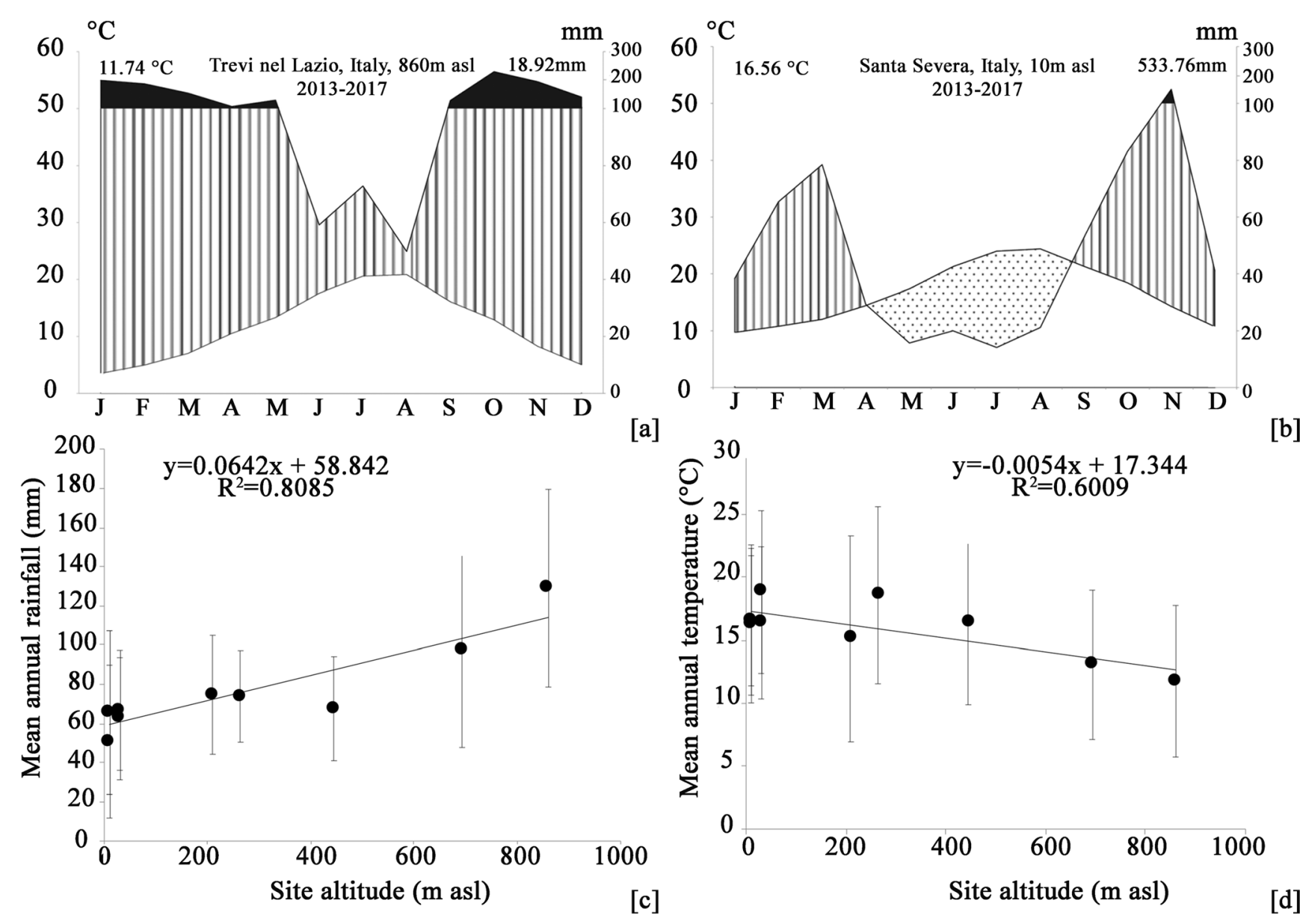

Fig. 2 Bagnoul-Gaussen graphs of the bioclimatic extremes. a Santa Severa, $\mathbf{b}$ Trevi nel Lazio sites; and $\mathbf{c}$ mean annual rainfall and $\mathbf{d}$ relative humidity correlation with altitude of the sites

A strong negative correlation between the diurnal light loads/aspects and biofilm cover $\left(R^{2}=0.816 ; p<0.005\right)$ was detected. The estimations of the daily light load at each site showed that T. umbrina had a preference for $\mathrm{N}$ and NW aspects that received low light loads (Fig. 4b).

Different substrates were colonised, but based on the number of observations, there seemed to be a preference for concrete and mortars (Fig. 4c), reaching the highest values for the concrete posts.

\section{Morphological and molecular characterisation}

All the collected biofilms resulted primarily composed of T. umbrina colonies. Confident identification of T. umbrina based on morphological analysis was possible even if no sexual structures were found in any of the samples (Fig. 5). Samples taken toward the centre of the red biofilms were composed almost entirely of T. umbrina cells with only a scarce presence of meristematic fungi. Closer to the edge of the red-orange biofilms, other phototrophs were present, including cyanobacteria such as Gloeothece sp., Gloeocapsa sp. or Scytonema sp., and a few small pennate diatoms.
The Kruskal-Wallace analysis of morphological measurements showed a high degree of variability, with significant differences in cell length and width among populations. Dunn's post hoc test identified around $50 \%$ out of a total of 60 comparisons were significantly different $(p<0.05)$ for both $L$ and $W$ data. Comparing the means of $L: W$ of intercalary cells of T. umbrina using an ANOVA revealed there was a significant difference between sites. Post hoc investigation, however, showed only RP1 was significantly different from OA1, $\mathrm{OA} 2$ and CA3 $(p<0.01)$; otherwise, this descriptor was relatively conservative. Scatter plots of the site-specific $W$ and $L: W$ mean values show the range of cell size within and among populations (Fig. 6) but also reveal the large overlap in the ranges among sites. Based on the 95th percentile values of all 600 cell measurements, we report an intercalary cell size range of (8.1) 13.5-27.5 (41.8) $\mu \mathrm{m}$ wide (Fig. 6a) and $L: W$ of 1.1-1.6, and a mean of 1.25 times longer than wide (Fig. 6b).

The rbcL sequence determined in this study $(610 \mathrm{bp})$ for strain GRAS2 (sample taken from Grassi Hospital) was submitted to the GenBank database with accession no. MK281583 and showed high sequence identity (97.2\%) with a sequence of $T$. umbrina voucher UNA00068462. The 
Fig. 3 Widespread and distribution of BP. a The abundance of the red-orange biofilm in the favourable condition of Grassi hospital. b The differences of colonisation related to the aspects (Santa Severa). c The ecological transition from red-orange BP to black BP (S. Marinella)

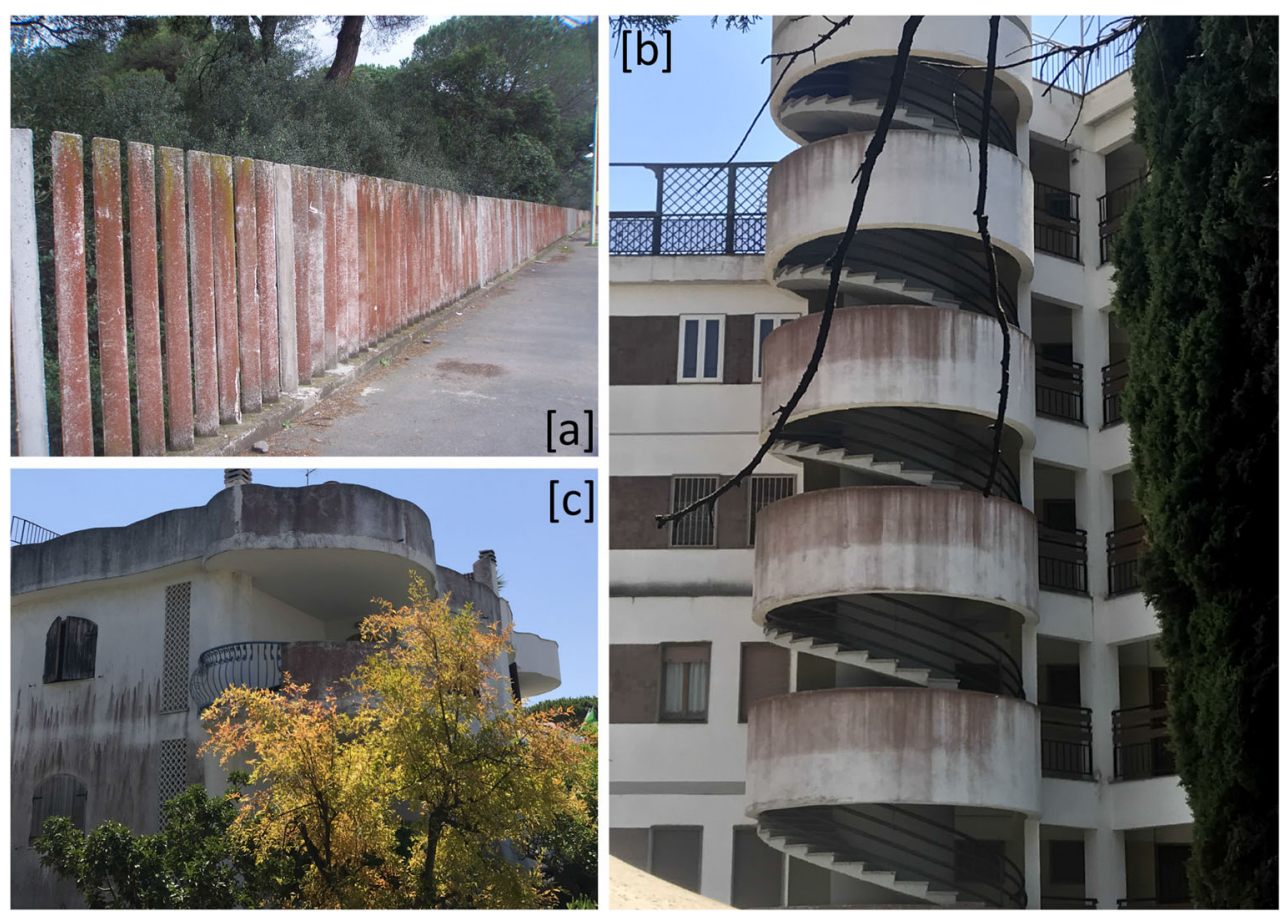

neighbour-joining tree (Fig. 7) obtained with a data set of 12 rbcL gene sequences had the same topology of trees inferred with by the maximum likelihood and parsimony methods (data not shown). Strain GRAS2 clustered with the strain of T. umbrina voucher UNA00068462 isolated from the bark of the tree on banks of river Ticino (Rindi et al. 2009) supported by a bootstrap value of $100 \%$. Another strain of Trentepohlia cf. umbrina isolated from a concrete wall in Ireland (Rindi et al. 2009) grouped in a different cluster along with other species of Trentepohliales. On the basis of morphological observations and molecular analyses, the strain GRAS2 investigated in this study can be assigned to the species T. umbrina.

\section{Discussion}

This study clarifies and improves the ecological and morphological characterisation of the species T. umbrina, also highlighting that this species, in its free-living, nonlichenized form, is much more widespread than the available literature suggests. T. umbrina is the most widespread species of the genus (Rindi and López-Bautista 2007), but records of its free-living form refer only to countries of tropical (Rindi et al. 2005, 2006; Gaylarde et al. 2006) and temperate climates (Rindi and Guiry 2002; Lüttge and Büdel 2010; Marmor and Degtjarenko 2014; Unković et al. 2017). There are Mediterranean records for the genus in Portugal (Pereira de Oliveira 2008; Macedo et al. 2009) and Spain (Alvarez et al. 1994; Ariño and Saiz-Jimenez 1996) but not specifically for the species T. umbrina.
Also, in Italy, the most records refer to the genus Trentepohlia (Tomaselli et al. 2000; Zucconi et al. 2012) or to the species T. aurea (Rizzi Longo et al. 1980), instead the only records of T. umbrina are from Pavia (Rindi et al. 2005) and Lucca (Ricci and Bartoli 2017). Therefore, this study shows for the first time the presence of T. umbrina in the Lazio region and more specifically in the area with Mediterranean bioclimate. This study shows many T. umbrina populations across a relatively small area (Lazio region), but due to the altitude differences among sites, a relatively large ecological gradient is covered $\left(12\right.$ to $19{ }^{\circ} \mathrm{C}$ and 554 to $1549 \mathrm{~mm} \mathrm{y}^{-1}$ rainfall, 5-year means), giving further data to the ecological characterisation of the species. Moreover, among the surveyed areas, six are considered to have cultural heritage value: Domus Augustana (Palatine hill, RM), the Non-Catholic Cemetery (RM), Ostia Antica archaeological park (RM), Bomarzo historic garden (VT), Villa Lante di Bagnaia (VT), Santuario Madonna del Tufo (Rocca di Papa). Three sites were considered as modern urban, such as facades of buildings (in Santa Severa and S. Marinella), concrete fence posts (Grassi Hospital) and concrete electricity poles (Trevi nel Lazio). The majority of literature on Trentepohlia as a biodeteriogen of monuments is related mainly to the genus Trentepohlia (Tomaselli et al. 2000; Caneva et al. 2005; Macedo et al. 2009; Zucconi et al. 2012; OrtegaMorales et al. 2012; Bartoli et al. 2014) and T. aurea (Noguerol-Seoane and Rifon-Lastra 1996; Ramirez et al. 2010), whereas records of T. umbrina are only limited to Tropical areas (Gaylarde et al. 2006; Samad and Adhikary 2008). Given the biodeteriogenic potential of this genus (Wakefield et al. 1996; Cutler and Viles 2010), the newly 


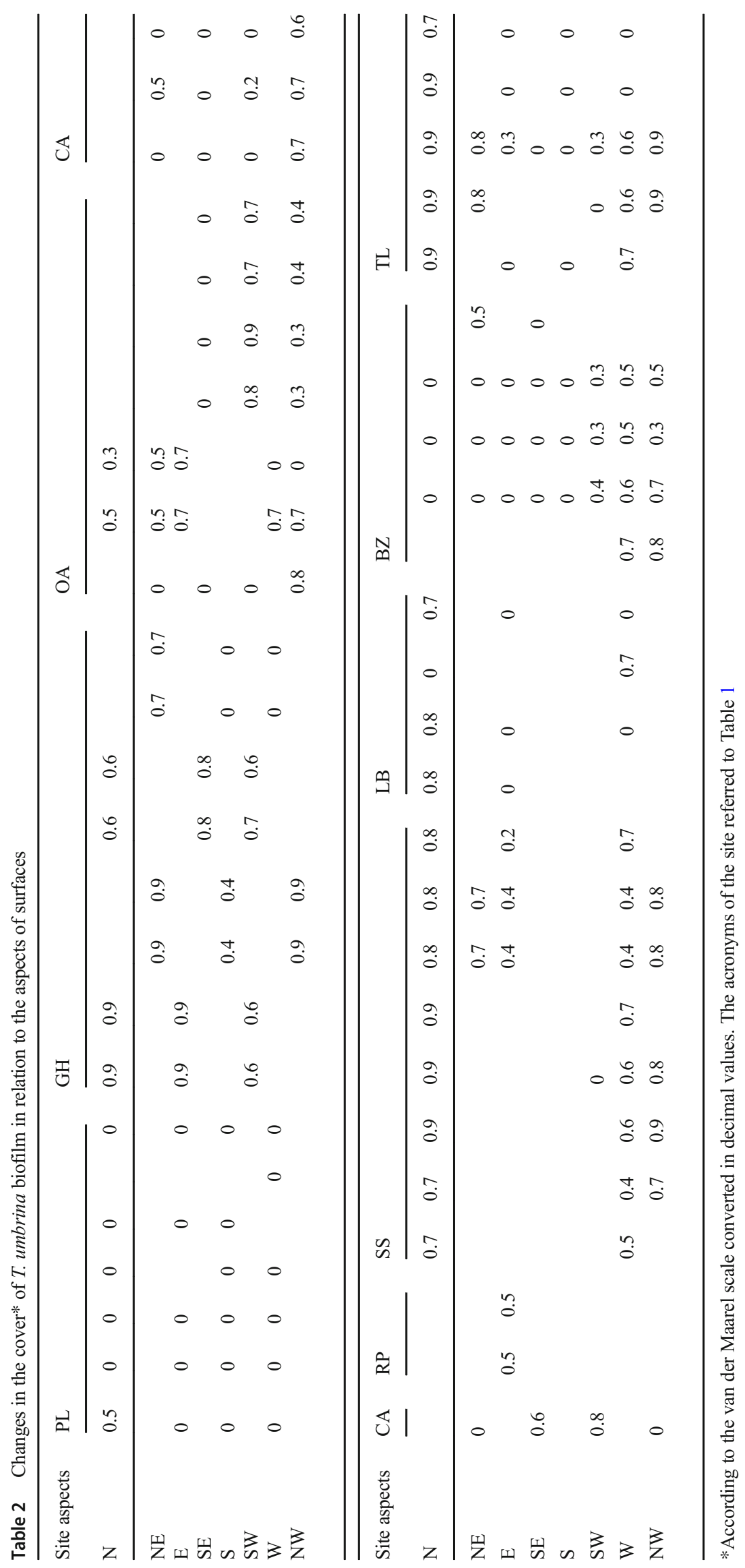




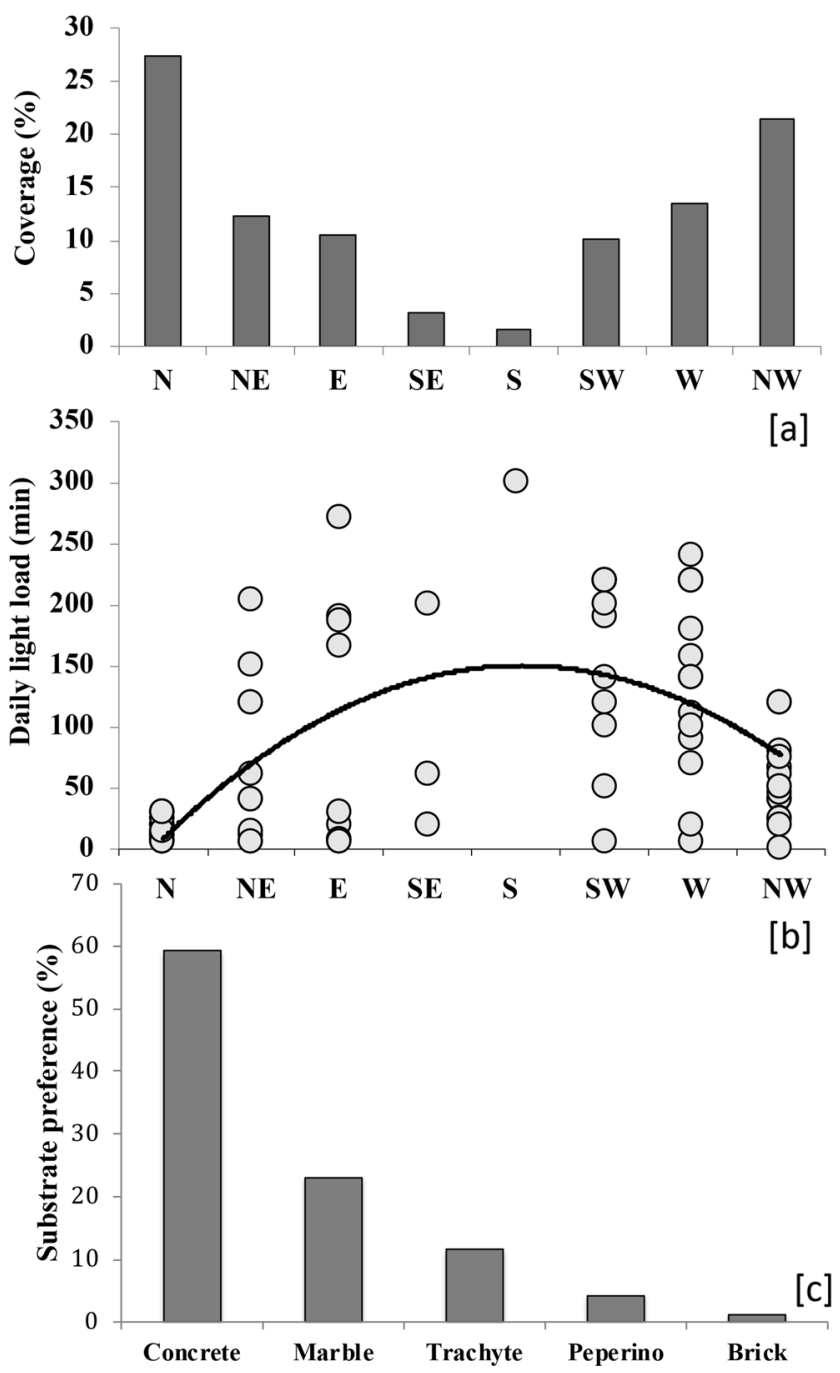

Fig. 4 Cover of BP (\% of total cover based on the mean for each aspect) in relation to $\mathbf{a}$ the aspects, $\mathbf{b}$ the light availability for each aspect and $\mathbf{c}$ the substrate

discovered presence of T. umbrina on sites of cultural heritage in Lazio is relevant for the conservation of monuments in these sites.

The most significant micro-climatic factors controlling algal growth on the lithic surface are generally moisture, light and temperature (Ariño and Saiz-Jimenez 1996; Tran et al. 2014; Caneva et al. 2016), which are also related to the surface chemico-physical conditions and aspects. In the case of T. umbrina, the need for substrate moisture was relatively low, considering that it occurs almost entirely on vertical, lithic surfaces. It is highly probable its water requirement is derived from atmospheric humidity and dew formation. Its main occurrence on northern aspects and in coastal areas supports this theory. The unusual presence of T. umbrina on a southern facing substrate at the Grassi Hospital seems associated with the nature of the substrate, which was very porous and in relatively humid conditions. In this particular south aspect, the humidity content related to the high substrate permeability will result in it holding on for longer to the minimum moisture level, higher than a classic southern aspect. If this is so, it would allow T. umbrina to be photosynthetically active for longer after sunrise than if the substrate was less adsorptive. This hypothesis could also go some way to explain the apparent preference for concrete within this survey, that has been shown to be particularly bioreceptive due to their combined roughness and porosity (Tran et al. 2014).

Humidity is normally higher in warmer air, but not when exposed to high solar radiation, so the main presence of T. umbrina on substrates with northern aspects would be expected. This can also help explain why T. umbrina seems to tolerate a wide temperature range (annual mean from 12 to $19{ }^{\circ} \mathrm{C}$ ), was not found on southern aspects in the higher altitude sites and why growth/biomass was more abundant at the warmer coastal areas; perhaps growth in the uplands simply continues but slower in comparison with that in the lowlands.

In the case of T. umbrina, it has been shown that light is among the most relevant growth limiting factors (Odum et al. 1971). The negative correlation between T. umbrina cover and light, and that light loads were mainly determined by substrate aspect, further underlines the low light preference. Toward the outer lower edge of the T. umbrina biofilms observed here, cyanobacteria, and other green algae and in some instances, diatoms were observed. These data would confirm the ecological model proposed by Caneva et al. 2016 showing the strong relationship between the ecological features of this species
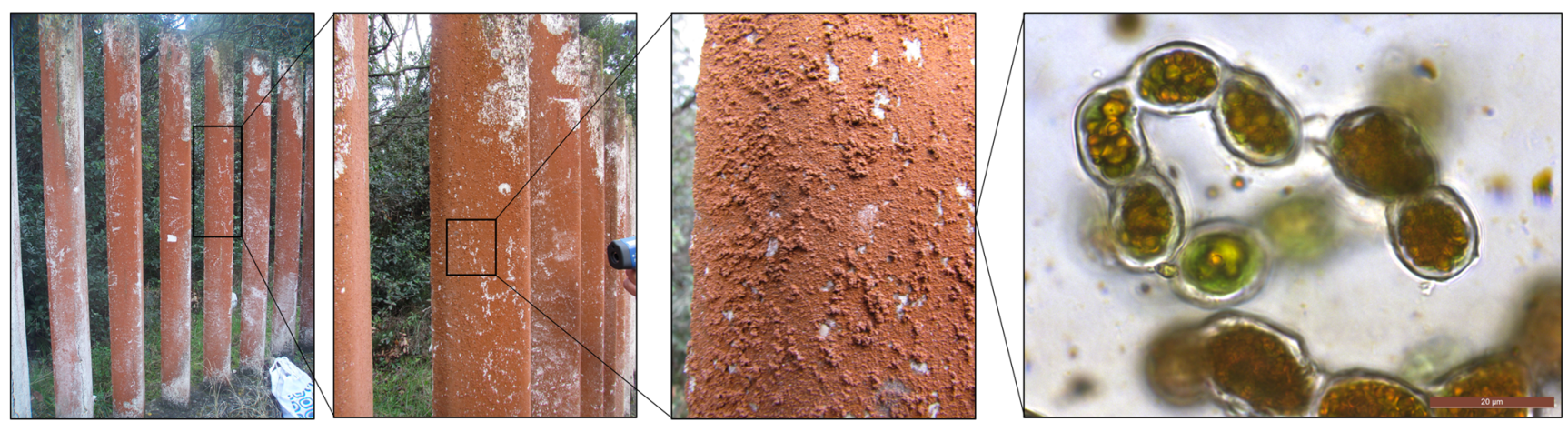

Fig. 5 T. umbrina from a macroscopic to a microscopic point of view 

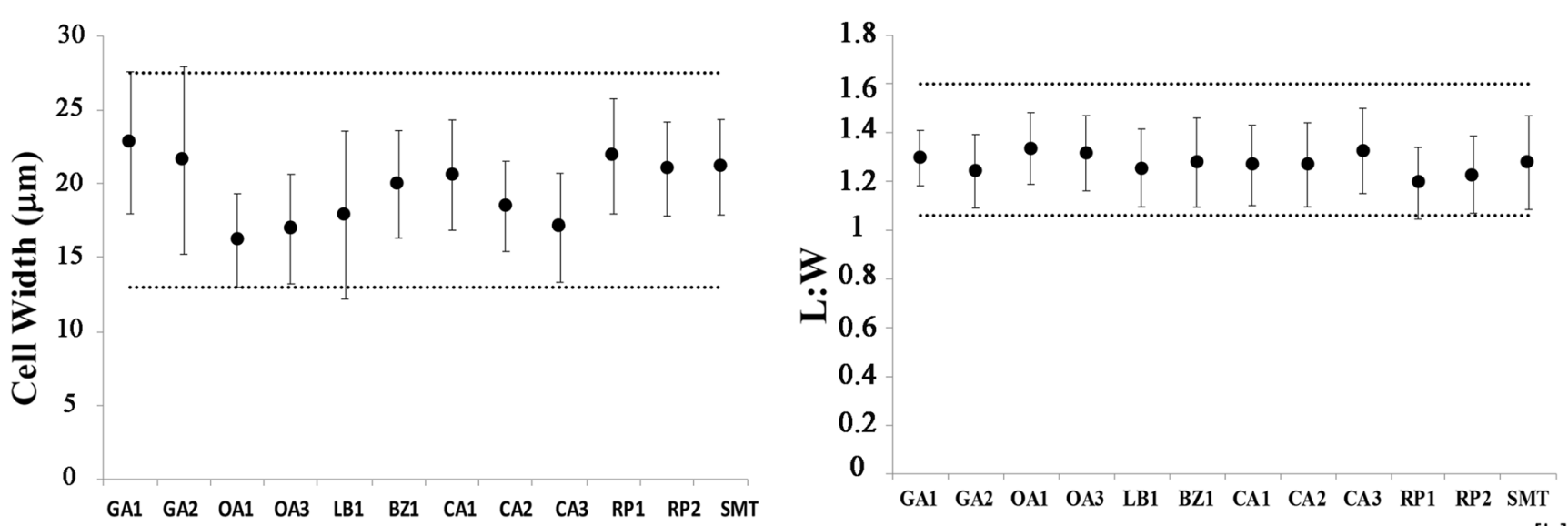

[a]

Fig. 6 Morphological measurements of intercalary cells of T. umbrina. Data are mean values with standard deviations for the sites (acronyms listed in Table 1). Dotted lines are the 95 th percentiles of the whole dataset ( 600 cells)

and cyanobacteria: it seems that situation in tropical and Mediterranean climates is similar, showing a transition from Trentepohlia-dominated community to a cyanobacteria community with an increase in light availability.

The cell dimension of all the populations included in this study was always close to the ranges set out by John (2002). Rindi and Guiry (2002), however, gave a smaller cell width range than in John (2002) at 8-20 $\mu \mathrm{m}$ compared with 15$27 \mu \mathrm{m}$. In total, there were 600 cells measured to give robust cell width range of 13 to 27.5 with a mean of 19.6. The $L: W$ range of 1 to 1.7 with a mean of 1.25 was a more restricted range than those previously reported of one to two times longer than wide. Cell width is recognised as an important morphological character in the taxonomy of Trentepohlia, and in this study, there was some variation among sites, but it was rare that it was significant, and all the widths within one standard deviation of the mean fell between the grouped 95th percentile range. Other morphological features worth noting include short irregular filaments frequently composed of two to four bulbous cells; however, John (2002) reported
Fig. 7 Neighbour-joining tree inferred from $12 \mathrm{rbcL}$ gene sequences $(610 \mathrm{bp})$. The numbers at the nodes indicate bootstrap values as a percentage greater than $50 \%$ obtained using distance as an optimality criterion with 500 replicates. The sequence determined in this study is indicated in bold. The sequences of Ulva australis and Ulva linza were designated as outgroup. The GenBank accession numbers are reported for each sequence. The scale marker represents 0.1 nucleotide substitution per sequence position

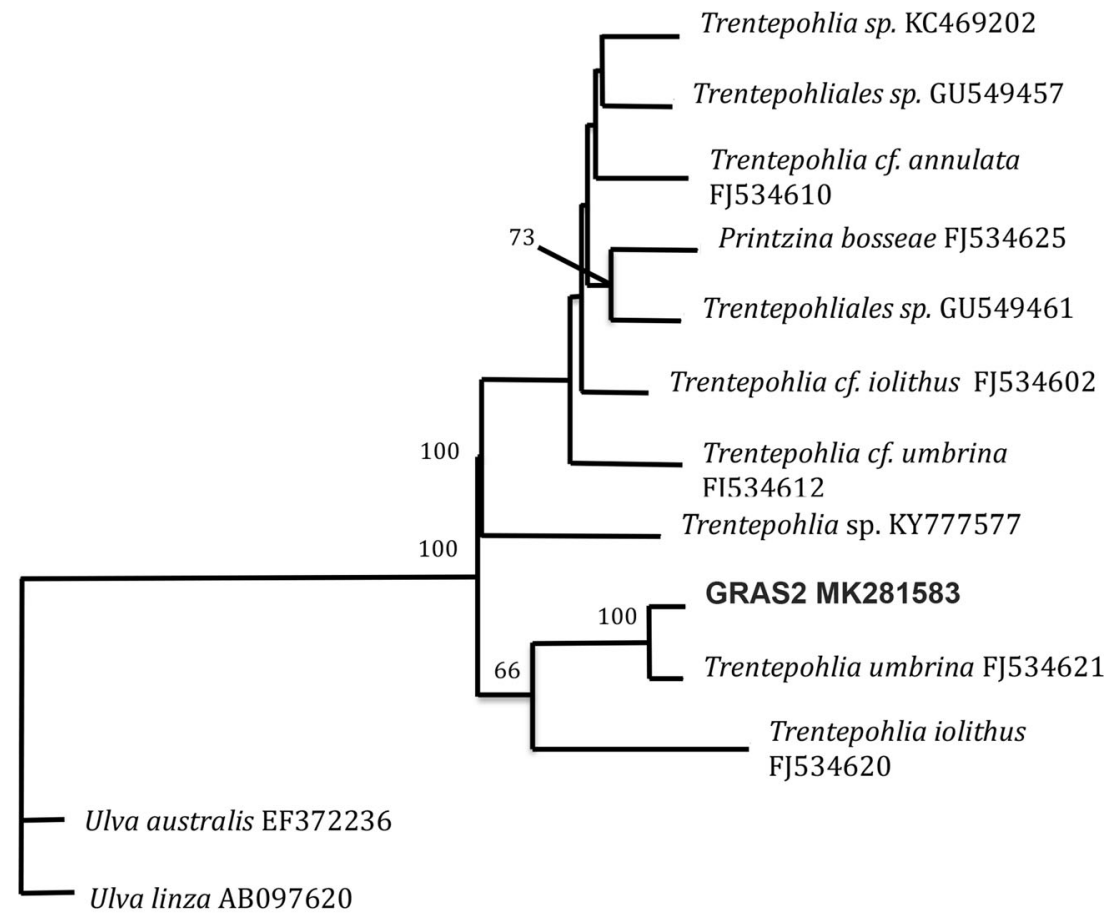


that these short filaments are possibly broken as a result of sample processing during sampling and slide preparation. There was no obvious distinction between prostrate and erect structures. Filaments are sometimes branched; this feature is possibly more common as this is likely the point where filaments break when being processed. Terminal cells are smaller at around $10 \mu \mathrm{m}$ and seem more regular in form than the intercalary cells. No sexual structures were noted during the period of the study nor during the numerous attempts to culture this species. Based on these morphological data and knowledge of the closely related species within this genus, it was possible to identify with some security the species observed as T. umbrina.

However, as previously established by Rindi et al. (2009), in the order Trentepohliales, the species concept cannot be based exclusively on morphological features. Thus, we carried out a molecular investigation in order to determine its taxonomic position using the rbcL gene, which has a better resolution than the 18S rRNA analysis in this species (Rindi et al. 2009). The results showed the high base similarity of our strain with another Italian strain of T. umbrina and so confirming the morphological identification of strain GRAS2 as the species T. umbrina with some certainty. Species of T. umbrina resulted as polyphyletic taxa, and in a previous study, some strains of T. umbrina clustered together with other species of Trentepohlia and Pritzina with a widespread geographical distribution (Rindi and Guiry 2002). In particular, different strains of T. umbrina clustered with strains of $T$. iolithus. However, it is worth of note that our strain from Ostia (Roma, Italy) clustered with the Italian (Pavia, Italy) strain of T. umbrina possibly indicative of environmental influence in the distribution of this species.

\section{Conclusions}

Free-living T. umbrina distribution is more widespread than previously thought. It is widely distributed within the Lazio region colonising a diverse range of substrates occurring across a wide ecological range from the Mediterranean to temperate climates. T. umbrina has a clear preference for vertical substrates with northern aspects, often associated with low light and humid conditions. Our research also refined the morphological features that describe the species and supported this with molecular techniques.

The importance of understanding the ecology of this species is becoming increasingly evident, as the information of its possible biodeteriogenic nature comes to the fore.

Funding Financial support to the research arises from the cooperation agreement among the Universities of Tor Vergata and Roma Tre (2016/2019).

\section{Compliance with ethical standards}

Conflict of interest The authors declare that they have no conflicts of interest.

Research involving human participants and/or animals No humans or animals were used in this work.

\section{References}

Albertano P (1995) Deterioration of Roman hypogea by epilithic cyanobacteria and microalgae. In: First International Congress on Science and Technology for the Safeguard of Cultural Heritage in the Mediterranean Basin, Catania, Siracusa, Italy, pp 1303-1308

Alvarez A, Argemi M, Laorden V, Domenech X, Verbal J, Navarro A, Prada JL, Puges M, Rocabayera R, Vilaseca L (1994) Physical, chemical and biological weathering detected in the romanic portal of the Sant Quirze de Pedret church (XIIc.). In: Fassina V, Ott H, Zezza F (eds) Proceedings of the 3rd International Symposium on the Conservation of Monuments in the Mediterranean Basin. Soprintendenza ai Beni Artistici e Storici di Venezia, Venice, pp 365-369

Anzalone B, Iberite M, Lattanzi E (2010) La flora vascolare del Lazio. Inf Bot Ita 42(1):187-317

Ariño X, Saiz-Jimenez C (1996) Colonization and deterioration processes in Roman mortars by cyanobacteria, algae and lichens. Aerobiologia 12(1):9-18

Bagnouls F, Gaussen H (1963) Os climas Biológicos e sua classificação. Bol Geogr 173:545-566

Bartoli F, Municchia AC, Futagami Y, Kashiwadani H, Moon KH, Caneva G (2014) Biological colonization patterns on the ruins of Angkor temples (Cambodia) in the biodeterioration vs bioprotection debate. Int Biodeterior Biodegradation 96:157-165. https://doi.org/ 10.1016/j.ibiod.2014.09.015

Bellinzoni AM, Caneva G, Ricci S (2003) Ecological trends in travertine colonization by pioneer algae and plant communities. Int Biodeterior Biodegradation 51:203-210. https://doi.org/10.1016/ S0964-8305(02)00172-5

Blasi C (1993) Carta del fitoclima del Lazio. Regionalizzazione e caratterizzazione climatica. Regione Lazio, Assessorato Agricoltura e Foreste, Caccia e Pesca, Usi civici. Università La Sapienza, Dip. to Biologia Vegetale, Roma

Braun-Blanquet J (1964) Pflanzensoziologie. Springler Verlag, Wien

Bruno L, Valle V (2017) Effect of white and monochromatic lights on cyanobacteria and biofilms from Roman catacombs. Int Biodeterior Biodegradation 123:286-295. https://doi.org/10.1016/j.ibiod.2017. 07.013

Bruno L, Bellezza S, De Leo F, Urzi C (2014) A study for monitoring and conservation in the Roman catacombs of St. Callistus and Domitilla, Rome (Italy). In: Saiz-Jimenez C (ed) The conservation of subterranean cultural heritage. CRC Press, Taylor \& Francis Group, pp. 37 44. ISBN 978-1-138-02694-0

Caneva G, Nugari MP, Ricci S, Salvadori O (1992) Pitting of marble roman monuments and the related micro-flora. In: Delgado J, Enriques F, Telmo F (eds) Seventh international congress on deterioration and conservation of stone LNNA, Lisbon, pp 521-530

Caneva G, Salvadori O, Ricci S, Ceschin S (2005) Biological analysis for the conservation of the hieroglyphic stairway of Copan (Honduras). LABS5. Biodegradation and biodeterioration in Latin America. Universidad de Campeche, Mexico, pp 55-58

Caneva G, Bartoli F, Ceschin S, Salvadori O, Futagami Y, Salvati L (2015) Exploring ecological relationships in the biodeterioration patterns of Angkor temples (Cambodia) along a forest canopy 
gradient. J Cult Herit 16(5):728-735. https://doi.org/10.1016/j. culher.2015.01.001

Caneva G, Bartoli F, Savo V, Futagami Y, Strona G (2016) Combining statistical tools and ecological assessments in the study of biodeterioration patterns of stone temples in Angkor (Cambodia). Sci Rep 6:32601. https://doi.org/10.1038/srep32601

Cutler N, Viles H (2010) Eukaryotic microorganisms and stone biodeterioration. Geomicrobiol J 27(6-7):630-646. https://doi.org/10.1080/ 01490451003702933

Danin A, Caneva G (1990) Deterioration of limestone walls in Jerusalem and marble monuments in Rome caused by cyanobacteria and cyanophilous lichens. Int Biodeterior Biodegradation 26:397-417. https://doi.org/10.1016/0265-3036(90)90004-q

Eggert A, Häubner N, Klausch S, Karsten U, Schumann R (2006) Quantification of algal biofilms colonising building materials: chlorophyll a measured by PAM-fluorometry as a biomass parameter. Biofouling 22(02):79-90. https://doi.org/10.1080/ 08927010600579090

Gaylarde CC, Gaylarde PM (2005) A comparative study of the major microbial biomass of biofilms on exteriors of buildings in Europe and Latin America. Int Biodeterior Biodegradation 55(2):131-139

Gaylarde CC, Morton LG (1999) Deteriogenic biofilms on buildings and their control: a review. Biofouling 14(1):59-74. https://doi.org/10. 1080/08927019909378397

Gaylarde CC, Gaylarde PM, Copp J, Neilan B (2004) Polyphasic detection of cyanobacteria in terrestrial biofilms. Biofouling 20(2):71-79. https://doi.org/10.1080/08927010410001681237

Gaylarde P, Englert G, Ortega-Morales O, Gaylarde C (2006) Lichen-like colonies of pure Trentepohlia on limestone monuments. Int Biodeterior Biodegradation 58(3-4):119-123. https://doi.org/10. 1016/j.ibiod.2006.05.005

Guiry MD, Guiry GM (2018) AlgaeBase. World-wide electronic publication, National University of Ireland, Galway. http://www. algaebase.org; searched on 03 October 2018

Ho KK, Tan KH, Wee YC (1983) Growth conditions of Trentepohlia odorata (Chlorophyta, Ulotrichales). Phycologia 22(3):303-308. https://doi.org/10.2216/i0031-8884-22-3-303.1

John DM (2002) Order Trentepohliales. In: John DM, Whittin BA, Brook AJ (eds) The freshwater algal flora of the British Isles. Cambridge University Press, Cambridge, pp 475-478

Lee KB, Wee YC (1982) Algae growing on walls around Singapore. Malayan Nat J

Lüttge U, Büdel B (2010) Resurrection kinetics of photosynthesis in desiccation-tolerant terrestrial green algae (Chlorophyta) on tree bark. Plant Biol 12(3):437-444. https://doi.org/10.1111/j.14388677.2009.00249.x

Macedo MF, Miller AZ, Dionísio A, Saiz-Jimenez C (2009) Biodiversity of cyanobacteria and green algae on monuments in the Mediterranean Basin: an overview. Microbiol 155(11):3476-3490. https://doi.org/10.1099/mic.0.032508-0

Marmor L, Degtjarenko P (2014) Trentepohlia umbrina on Scots pine as a bioindicator of alkaline dust pollution. Ecol Indic 45:717-720. https://doi.org/10.1016/j.ecolind.2014.06.008

Noguerol-Seoane A, Rifon-Lastra A (1996) Epilithic ficoflora on two monuments of historic-artistic interest from Galicia (N.W. Spain). In degradation and conservation of granitic rocks in monuments. Environmental Protection and Conservation of the European Cultural Heritage, pp. 417-421, Research Report no. 5. Brussels: European Commission Directorate-General XII: Science, Research and Development

Odum EP, Odum HT, Andrews J (1971) Fundamentals of ecology, vol 3. Saunders, Philadelphia

Ortega-Morales BO, Gaylarde C, Anaya-Hernandez A, Chan-Bacab MJ, De la Rosa SC, García D (2012) Orientation effects of Trentepohliadominated biofilms on Mayan monuments of the Rio Bec style. Int
Biodeterior Biodegradation 30:1-6. https://doi.org/10.1016/j.ibiod. 2012.07.014

Pereira de Oliveira B (2008) Caracteriza cã o de filmes negros em pedras gran' ticas. O caso de estudo da Igreja da Ordem de São Francisco do Porto. MSc thesis, Universidade Nova de Lisboa, Lisbon, Portugal

Pinna D (2014) Biofilms and lichens on stone monuments: do they damage or protect? Front Microbiol 5(133):1-3. https://doi.org/10.3389/ fmicb.2014.00133

Ramirez M, Hernandez-Marine M, Novelo E, Roldán M (2010) Cyanobacteria-containing biofilms from a Mayan monument in Palenque, Mexico. Biofouling 26(4):399-409. https://doi.org/10. 1080/08927011003660404

Ricci S, Bartoli F (2017) Alghe e cianobatteri. In: Caneva G, Tomei P (eds) M - I/U - RABILIA - Un giardino verticale sulle mura di Lucca. Gangemi Editore, Roma, pp 39-49

Ricci S, Pietrini AM (1994) Caratterizzazione della microflora algale presente sulla Fontana dei Quattro Fiumi, Roma. In: La conservazione dei monumenti nel bacino del Mediterraneo: atti del $3^{\circ}$ simposio internazionale, 22-25 giugno 1994 Venezia, pp 353357

Rindi F, Guiry MD (2002) Diversity, life history, and ecology of Trentepohlia and Printzina (Trentepohliales, Chlorophyta) in urban habitats in western Ireland. J Phycol 38(1):39-54. https://doi.org/10. 1046/j.1529-8817.2002.01193.x

Rindi F, Guiry MD (2004) Composition and spatial variability of terrestrial algal assemblages occurring at the bases of urban walls in Europe. Phycologia 43(3):225-235

Rindi F, López-Bautista JM (2007) New and interesting records of Trentepohlia (Trentepohliales, Chlorophyta) from French Guiana, including the description of two new species. Phycologia 46(6): 698-708. https://doi.org/10.2216/06-88.1

Rindi F, Sherwood AR, Guiry MD (2005) Taxonomy and distribution of Trentepohlia and Printzina (Trentepohliales, Chlorophyta) in the Hawaiian islands. Phycol 44(3):270-284

Rindi F, Guiry MD, López-Bautista JM (2006) New records of Trentepohliales (Ulvophyceae, Chlorophyta) from Africa. Nova Hedwigia 83(3-4):431-449. https://doi.org/10.1127/0029-5035/ 2006/0083-0431

Rindi F, Lam DW, López-Bautista JM (2009) Phylogenetic relationships and species circumscription in Trentepohlia and Printzina (Trentepohliales, Chlorophyta). Mol Phylogenet Evol 52(2):329 339. https://doi.org/10.1016/j.ympev.2009.01.009

Rizzi Longo L, Poldini L, Goia F (1980) La microflora algale delle pareti calcaree del Friuli-Venezia Giulia (Italia nord-orientale). EUT Edizioni Università di Trieste

Samad LK, Adhikary SP (2008) Diversity of micro-algae and cyanobacteria on building facades and monuments in India. Algae 23(2):91-114. https://doi.org/10.4490/ALGAE.2008.23.2.091

Scheerer S, Ortega-Morales O, Gaylarde C (2009) Microbial deterioration of stone monuments-an updated overview. Appl Microbiol 66: 97-139. https://doi.org/10.1016/S0065-2164(08)00805-8

Tomaselli L, Lamenti G, Bosco M, Tiano P (2000) Biodiversity of photosynthetic micro-organisms dwelling on stone monuments. Int Biodeterior Biodegradation 46(3):251-258. https://doi.org/10. 1016/S0964-8305(00)00078-0

Tran TH, Govin A, Guyonnet R, Grosseau P, Lors C, Garcia-Diaz E, Damidot D, Devès O, Ruot B (2014) Influence of the intrinsic characteristics of mortars on their biofouling by pigmented organisms: comparison between laboratory and field scale experiments. Int Biodeterior Biodegradation 86:334-342. https://doi.org/10.1016/j. ibiod.2013.10.005

Traversetti L, Bartoli F, Caneva G (2018) Wind-driven rain as a bioclimatic factor affecting the biological colonization at the archaeological site of Pompeii, Italy. Int Biodeterior Biodegradation 134:3138. https://doi.org/10.1016/j.ibiod.2018.07.016 
Unković ND, Popović SS, Stupar MČ, Samolov ED, Subakov-Simić GV, Ljaljević-Grbić MV, Vukojević JB (2017) Biofilm forming microorganisms on various substrata from greenhouse of botanical garden "Jevremovac". Matica Srpska J Nat Sci 132:57-67. https://doi.org/ 10.2298/ZMSPN1732057U

van der Maarel E (1979) Transformation of cover-abundance values in phytosociology and its effect on community similarity. Vegetatio 39 : $97-114$

Wakefield RD, Jones MS, Wilson MJ, Young ME, Nicholson K, Urquhart DC (1996) Investigations of decayed sandstone colonised by a species of Trentepohlia. Aerobiologia 12(1):19-25
Wee YC, Lee KB (1980) Proliferation of algae on surfaces of buildings in Singapore. Int Biodeterior Bull 16(4):113-117

Zucconi L, Gagliardi M, Isola D, Onofri S, Andaloro MC, Pelosi C, Poliani P, Selbmann L (2012) Biodeterioration agents dwelling in or on the wall paintings of the Holy Saviour's cave (Vallerano, Italy). Int Biodeterior Biodegradation 70:40-46. https://doi.org/10.1016/j. ibiod.2011.11.018

Publisher's note Springer Nature remains neutral with regard to jurisdictional claims in published maps and institutional affiliations. 